\title{
LIBERALIZACJA W UNII EUROPEJSKIEJ I NIE ROZWIĄZANY EUCKENOWSKI DYLEMAT
}

\begin{abstract}
Streszczenie
Na wstępie artykułu wykazano, że liberalizacyjna misja Unii Europejskiej jest złożona. Jednym z problemów zastanych jest przyzwolenie przez państwa członkowskie na koncentrację siły ekonomicznej lub wręcz ochrona grup dominujących w gospodarce. W części drugiej nawiązano do opinii Waltera Euckena, zgodnie z którą ta skłonność państwa kapitalistycznego stanowiła fundamentalny problem budowy ustroju opartego na konkurencji, który jednak mogło rozwiązać tylko państwo. Owo zapętlenie nazywano euckenowskim dylematem i postawiono pytanie, czy nadzór ponadnarodowych organów Unii Europejskiej współcześnie tworzy szanse na rozbijanie układu między państwem narodowym a rodzimymi monopolami. Część trzecią oparto na praktycznych doświadczeniach krajów członkowskich Unii Europejskiej i dotyczy ona sfery usług użyteczności publicznej, której specyfika sprzyja tego typu związkom między państwem a biznesem, odnosząc się do zasad unijnych. Ów przegląd zakończono wnioskiem, że Unia, występująca w roli orędownika wspólnego jednolitego rynku, nie wydaje się gotowa na konfrontację $z$ wielkimi firmami z sektorów sieciowych ani wspierającymi „swoje” firmy państwami. Tak długo, jak będzie na to za słaba lub nie dość zdeterminowana, głoszona przez nią zasada konkurencji w sensie euckenowskim będzie w dalszym ciagu należeć do przyszłości.
\end{abstract}

Słowa kluczowe: regulacje europejskie, powszechne usługi użyteczności publicznej, poszukiwanie renty

\section{ECONOMIC LIBERALISATION IN EUROPEAN UNION AND EUCKEN'S DILEMMA}

\section{Summary}

The paper begins with a discussion of the complexity of EU's liberalisation mission. Among the problems faced is the fact that member-states have long tolerated the concentration of economic power, or even protected the interests of the dominant economic entities. In the second section, the author refers to Walter Eucken's observation that this feature of the capitalist state constituted a major barrier to a competitive market, which could be eradicated exclusively by the state itself. This trade off has been referred to as Eucken's dilemma. The central question is whether the supervision of supra-national institutions of the EU is capable of severing the ties between the national state and the domestic monopolies. Section three examines the evidence from the field of services of general economic interest, where these ties are extremely strong. The review concludes that, in spite of its programme for the promotion of a common unified market, the European Union is not in a position to confront large businesses from the network industries, or the states which provide support for them. As long as the $\mathrm{EU}$ is too weak or too hesitant, the idea of the competitive order, the Eucken's heritage, is unlikely to become a reality.

Key words: European regulatory framework, universal services of general interest, rent seeking

DOI: 10.15290/ose.2015.01.73.04

1 Prof. dr hab. Anna Zabkowicz - Instytut Nauk Ekonomicznych PAN; e-mail: holic@op.pl; doc. dr Jerzy Ząbkowicz - Uczelnia Techniczno-Handlowa im. H. Chodkowskiej; e-mail: j.zabkowicz@yahoo.com. 


\section{Wstęp: liberalizacyjna misja Unii Europejskiej}

Zestawienie słowa 'liberalizm' z 'interwencjonizmem' odczytuje się jako wskazanie na liberalizm rynkowy. Opiera się on na racjonalności i spontanicznym porządku, na uznaniu suwerenności i własnego interesu jednostki oraz prywatnego prawa własności [Wojtyna, 1994, s. 20]. Państwo w tej indywidualistycznej wizji jest potrzebne, aby korygować rynek tak, by w sposób skuteczny przekazywał preferencje ludzi. Powinno to czynić za pomoca znanych popwszechnie reguł, wstrzymując się od interwencjonizmu pod postacia polityki przemysłowej, protekcjonizmu itp. [Wojtyna, 1994, s.17-18]. Powinno się samoograniczać, gdyż nigdy nie będzie dysponowało informacją na temat cen lepszą niż zapewnia rynek. Wymiana musi odbywać się pod rządami prawa (rule of law), co oznacza, że państwo nikogo nie uprzywilejowuje, w tym siebie. W ujęciu F. A. Hayeka, tak zwane względy społeczne (poza nielicznymi wyjątkami) nie powinny mieć znaczenia, ponieważ prowadzą do nierówności obywateli względem prawa i dają mandat państwu do nadużywania władzy.

Jednak wielu myślicieli, uważających się za liberałów, nie podziela tej postawy poznawczej, uznając za nieodłączny warunek wolności człowieka poczucie bezpieczeństwa i odpowiedzialność za nie przypisując przede wszystkim państwu. Tak rozumiany liberalizm w systemie gospodarki opartej na własności prywatnej i swobodzie prywatnej inicjatywy nakłada na państwo jako nadrzędną organizację społeczną obowiązek przeciwdziałania znacznym obszarom nędzy, masowego bezrobocia, zaniedbaniom w dziedzinie ochrony zdrowia i środowiska naturalnego, edukacji i kultury [Sadowski, 1996; Walicki, 2013]². Tym samym rola państwa jest znacznie większa niż byliby skłonni przyznać zwolennicy liberalizmu rynkowego i przede wszystkim opiera się na względach społecznych.

Pomiędzy tymi dwoma liberalnymi światopoglądami mieści się między innymi myśl Waltera Euckena i w znacznej mierze ukształtowany przez nią ordoliberalizm. Eucken [Eucken, 2005] przyznając wyższość koordynacji gospodarowania za pośrednictwem cen nad biurokratycznym sterowaniem, jednocześnie przywiązuje wagę do określonych wartości społecznych (der ehre Kaufmann) i bezpieczeństwa, jakie może zapewnić subsydiarne państwo. Przyjęło się sądzić, że nurt ordoliberalny wywarł wpływ na ustrojowe myślenie w Republice Federalnej Niemiec i z jej udziałem znalazł przełożenie na projekty integracji europejskiej [Społeczna gospodarka rynkowa..., 2003].

Z powyższych uwag wynika, że liberalizm Unii Europejskiej, którego wpływy od 10 lat obejmują także większość krajów Europy Środkowo-Wschodniej, nie ma charakteru wyłącznie ekonomicznego. Przywiązuje bowiem wagę do wartości sprzyjających spójności społeczeństwa i pozostawia w tym znaczną rolę państwu. Z drugiej strony powołaniem Unii Europejskiej jest budowa wspólnego rynku, na którym zostałyby ujednolicone reguły konkurencji. Zgodnie z Traktatem o funkcjonowaniu Unii Europejskiej [Traktat o funk.jonowaniu Unii Europejskiej, 2010], Unia sprzyja równemu dostępowi do rynku oraz monitoruje liberalizację warunków gospodarowania w krajach członkowskich gwoli większej konkurencyjności na terenie całej Unii Europej-

2 Porównaj: [Manifest Międrynarodowej Asocjacji Liberatów, 1981]. 
skiej. Zatem ideę wolnego rynku, propagowana przez liberalizm rynkowy, Unia stawia bardzo wysoko w hierarchii ważności, choć nie traktuje jej nadrzędnie.

W tym artykule i zawartym w nim studium przypadku zwrócono uwagę na dwie istotne okoliczności, w których Unia usiłuje prowadzić politykę spójności i politykę równego dostępu do rynku. Jedna z nich jest władza i zakres kompetencji państw członkowskich, który niekiedy skłania do swoistej pokusy nadużycia na szczeblu narodowych organów publicznych. Między państwami narodowymi oraz instytucjami Unii tli się immanentny konflikt kompetencyjny. Drugą okolicznością wartą uwagi jest kontrowersyjne znaczenie wielkich firm jako uczestnika i podmiotu budowy jednolitego rynku europejskiego. Z jednej strony wielki biznes okazał się znaczącą siłą napędową obecnego etapu integracji w Europie. Z drugiej strony w sytuacji, gdy prywatne organizacje ekonomiczne maja dość siły, aby wpływać na reguły gry w gospodarce i utrzymują bliskie stosunki z państwem narodowym, dyskryminowane są zarówno podmioty zagraniczne, jak i większość krajowych, nieuprzywilejowanych podmiotów gospodarczych. Uwydatnienie tej bariery konkurencji było, zdaniem autorów, wyjątkową zasługą Waltera Euckena, a także uświadomienie, że od jej rozbicia zależy konstytucja ładu gospodarczego opartego na „konkurencji osiagnięć” (w odróżnieniu od konfrontacji siły ekonomicznej).

Jak widać, liberalizacyjna misja Unii nie jest wolna od napięć. W celu ostrzejszego zarysowania tych dylematów posłużono się przypadkiem sektora usług użyteczności publicznej. Na przykładzie „europejskiej” regulacji tego sektora dobrze widać, jak Unia stara się pogodzić dwa konkurencyjne - jak się wydaje - cele, mianowicie zwiększanie domeny wolności gospodarczej i efektywną realizację misji użyteczności publicznej. Nie byłoby dylematu, jak zapewnić dostępność i zarazem ekonomiczną efektywność tego rodzaju usług w Unii Europejskiej, gdyby nie ranga wartości społecznych i uznanie niezbywalnej roli państwa w szerszym zakresie niż tylko rządy prawa. W tej dziedzinie również wyraźnie widać, że koncentracja siły ekonomicznej często bywa nie tyle rezultatem zwycięstwa w konkurencji, co wynika z okoliczności pozaekonomicznych, na przykład zmowy kartelowej lub protektoratu państwowego. W sektorze usług użyteczności publicznej stan prawny i zaszłości szczególnie sprzyjają monopolizacji zamówień publicznych, nieuzasadnionej pomocy publicznej i tworza warunki do pogoni za renta. Rozwinięte gospodarki kapitalistyczne borykają się z tak rozumiana protekcja państwa co najmniej od czasów, które analizował Eucken, a współczesna organizacja integrująca te gospodarki, czyli Unia Europejska, odziedziczyła te problemy.

Wraz z akcesją w 2004 roku osiem krajów postsocjalistycznej Europy zostało włączone w system instytucjonalny Unii Europejskiej. Z przystapieniem do ugrupowania najsilniejszych gospodarek rynkowych wiązano między innymi oczekiwania, że posłuży ono instytucjom promującym liberalizm rynkowy w kraju wstępującym. W artykule pokazano, że nadzieje takie opierają się na nadmiernym uproszczeniu. Innymi słowy, liberalizacyjna misja organów europejskiej integracji jest bardziej złożona. Sprzyjanie konkurencji w gospodarce łączy się bowiem z równoległym zadaniem wzmocnienia spójności społecznej i wymaga mierzenia się z niektórymi ustrojowymi problemami państwa kapitalistycznego. 


\section{Euckenowski dylemat i misja Unii Europejskiej}

Z perspektywy ordoliberałów rynek konkurencyjny nie jest bynajmniej prawem „naturalnym”. Społeczeństwo samo z siebie nie wytwarza samoistnie działającego ładu, opartego na wolnej wymianie rynkowej, wymaga więc podtrzymania ze strony zorganizowanej władzy. Gospodarka uprzemysłowiona raczej wykazuje naturalną tendencję do eliminowania konkurencji i zastępowania jej przez oligopole i monopole. Uznanie koncentracji władzy ekonomicznej za problem prowadzi ordoliberałów do przywiazania wagi do jakości władzy politycznej jako rozwiązania problemu [Federowicz, 2004, s. 202-203].

Jak można zbudować efektywne państwo prawne, czyli państwo zdolne do ustanowienia i obrony ustroju gospodarczego opartego na konkurencji? Obraz, nakreślony przez Waltera Euckena na podstawie obserwacji kapitalizmu z przełomu XIX i XX wieku, doprowadził do wniosku, że państwo zawiodło w sensie zapewnienia uczciwej konkurencji, dopuszczając do opacznego wykorzystania wolności umów (kartele i syndykaty) i chroniąc grupy dominujące w gospodarce. Jednak to państwo właśnie wskazywał on jako jedyną siłę zdolną wspierać nowy „,ustrój oparty na konkurencji”. Odpowiednie zasady konstytucyjne stanowione przez państwo miały z czasem ograniczyć i wyplenić monopol, stworzyć równy dostęp do rynku oraz przestrzeń dla „,konkurencji osiagnięć". Mimo to Eucken przyznaje się do bezsilności. Jest bowiem świadomy, że z kwestia nadzoru nad monopolami zmierzyło się wiele państw przemysłowych i doświadczenie pokazuje, iż skutecżny nadzór nad monopolem w ustroju gospodarczym, w którym duże polacie przemystu sa zmonopolizowane, przekeracza sity nowoczesnego panstwa [Eucken, 2005, s. 332].

Idea państwa prawnego wymaga, aby najpierw samo państwo wyzwoliło się spod dominacji karteli i syndykatów. Istnieje współzależność: bez ustroju opartego na konkurencji nie może powstać żadne zdolne do driatania państwo, a bez takiego państwa - żaden oparty na konkurencii ustrój gospodarcsy [Eucken, 2005, s. 379]. Owo zapętlenie, którego Eucken nie rozwiązał, czyli zaklęte koło władzy ekonomicznej i władzy publicznej, nazwano tutaj euckenowskim dylematem.

Wskazana wydaje się dygresja, wyjaśniająca dlaczego w tej narracji słowo 'monopol' jest używane zamiennie $z$ kartelami. W ekonomii funkcjonuja pojęcia siły monopolistycznej (monopoly power) i siły przetargowej (bargaining power), które są odbiciem istnienia form organizacji w sferze: produkcji, finansów i wymiany, służących osiagnięciu pozycji dominującej na rynku. Ekonomia konwencjonalna widzi sytuację monopolu naturalnego oraz zdominowania rynku w rezultacie wzrostu wewnętrznego przedsiębiorstwa i stawia kwestię, na ile i czy władze publiczne poprawiają obserwowana zawodność rynku dzięki regulacji i kontroli. Ekonomia polityczna, rozwijająca się na obrzeżach głównego nurtu i poza nim, dostrzega, że renta monopolowa może być przechwytywana nie tylko za pośrednictwem ceny monopolowej, która jest wyższa od ceny rynkowej, lecz także w następstwie decyzji biurokratycznych, prawnych czy politycznych [Teoria myboru publicznego, 2012, s. 238-278]. Wzmocnienie pozycji na rynku daje władz̧. Podmioty ekonomiczne dążą do dominacji między innymi przez prywatną umowę lub zmowę, tworząc ugrupowania biznesowe. Przykładem może być kartel albo swoiste stowarzyszenie kapitałowe, jakim jest spółka akcyjna (korporacja). Obser- 
wacja wskazuje, że władze publiczne mogą przeciwdziałać (prawo antytrustowe), ale mogą również sprzyjać różnym formom koncentracji siły ekonomicznej. Szczególne stosunki między władzą publiczną a grupami nacisku moga prowadzić do uprzywilejowania niektórych podmiotów za pomocą prawa gospodarczego. Źródłem sztucznej renty mogą być: protekcjonizm (cła, kontyngenty, licencje, subsydia eksportowe), pomoc publiczna (oprócz wydatków rządowych, preferencje podatkowe i kredytowe), procedury związane z uruchamianiem i prowadzeniem działalności gospodarczej (koncesje, licencje, system podatkowy) i inne regulacje (np.: limity cen, ograniczenia terytorialne działalności). Szczególną sytuacja, którą omówiono w trzeciej części artykułu, jest ustanowienie monopolu prawnego, kiedy rząd nadaje firmie wyłączne prawo dostarczania określonego dobra na określonym terytorium. Reasumując, problem 'monopolu' w ujęciu Euckena nie odnosi się do podręcznikowych przypadków, lecz stawia kwestie władzy. Problem wyrasta bowiem z władzy, jaka daje dominacja gospodarcza i z faktu, że we współczesnej gospodarce grupy o znacznej sile rynkowej wchodzą z władzą państwową we wzajemne relacje.

Ponadnarodowe organa Unii mogą być postrzegane jako siła, która jest władna skutecznie ograniczyć dominująca pozycję ekonomicznych grup nacisku osiagnięta w dużym stopniu dzięki szczególnym stosunkom z państwem narodowym. Władza, którą faktycznie dysponują organa ponadnarodowe, może zastąpić w tej roli państwo, które okazało się zbyt słabe, aby stać na straży jednolitych reguł gry dla wszystkich uczestników rynku. $Z$ tej perspektywy Unia jawi się jako szansa na zapewnienie równego dostępu i jednolitych reguł gry dla wszystkich podmiotów działających we wspólnej europejskiej przestrzeni gospodarczej.

\section{Egzemplifikacja: usługi użyteczności publicznej}

Czy nadzór ponadnarodowych organów Unii Europejskiej rzeczywiście tworzy szanse na rozbijanie układu między państwem narodowym a rodzimymi monopolami? Czy Unia godzi wymóg efektywności działalności gospodarczej z zachowaniem wartości społecznych? Do ilustracji tych zagadnień wyjątkowo dobrze nadaje się „rynek” usług użyteczności publicznej. Po pierwsze, ze względu na społeczny charakter usług rola państwa narodowego jest tu niezwykle znacząca. Po drugie, ze względu na zaszłości wiele państw utrzymuje szczególnie bliskie stosunki z dominującymi w branży przedsiębiorstwami o zakorzenionych interesach (vested interests). W sumie powoduje to dość silne napięcie między państwami członkowskimi a ponadnarodowymi organami Unii.

Organy Unii uznają doniosłość zapewnienia usług użyteczności publicznej (w tym usług powszechnych) $\mathrm{i}$ cedują to zadanie na kraje członkowskie, bowiem odpowiedź rynku byłaby $\mathrm{w}$ tym przypadku z pewnością ułomna, gdyż w tym sektorze przede wszystkim liczy się misja społeczna i dostępność usługi. Społeczny charakter dobra jest widoczny zwłaszcza w przypadku usług użyteczności publicznej o charakterze powszechnym (ang. universal service, fr. service universe). Dyrektywa Parlamentu Europejskiego $i$ Rady $z$ dnia 7 marca 2002 roku w spranie ustugi ponszechnej $i$ zwiqzanych z sieciami i ustugami taczności 
elektroničnej praw uisytkownikón (dalej: dyrektywa o usłudze powszechnej) głosi, że usługa świadczona w interesie ogólnym o charakterze usługi powszechnej musi być dostępna: w określonej jakości dla wsyystkich uisytkowników końconych, niezależnie od geograficżnego umiejscowienia oraz ₹. uñ zglednieniem konkretnych warunkón krajonych, po praystępnej cenie [Dyrektywwa..., 2002, art. 3, pkt 1]. Chodzi zatem o tę grupę usług użyteczności publicznej, do których maja prawo wszyscy użytkownicy końcowi, czyli także osoby zagrożone wykluczeniem, na przykład o niskich dochodach lub zamieszkujące peryferyjne obszary krajów członkowskich Unii Europejskiej. Należą do nich usługi pocztowe, łączność elektroniczna i inne. $\mathrm{Na}$ szczeblu unijnym są określane wspólne zasady, zaś ich wdrażanie pozostaje w gestii państw narodowych. Według Białej Księgi z 2004 roku [Komunikat Komisji..., 2004, s. 9], takie podejście umożliwia uwzględnienie konkretnej sytuacji panującej w każdym z tych państw. Przyjęcie zasady usługi powszechnej oraz taki podział ról i uprawnień w Unii Europejskiej należy wiązać z jednym ze wspólnotowych priorytetów, mianowicie zapewnieniem spójności społecznej i terytorialnej Unii Europejskiej.

Niemniej również w tym sektorze Unia stara się wdrożyć zasadę równego dostępu, zgodnie z którą do zamówień publicznych są dopuszczane podmioty skomercjalizowane albo nastawione na zysk. W rezultacie mamy do czynienia z dość kontrowersyjną sytuacja: misja publiczna jest obecnie realizowana przez podmioty działające na rynku, przy czym społeczny charakter misji czyni dopuszczalne wsparcie ze strony państwa. Pojawia się kwestia, czy działanie na rzecz pożytku publicznego przy pomocy państwa nie wpływa na pozycję wykonawców względem innych, konkurujących z nimi podmiotów. Jednym słowem, pojawia się problem zasadności pomocy publicznej i szereg trudności związanych z egzekwowaniem generalnego zakazu jej udzielania.

W konsekwencji między państwami członkowskimi i organami Unii tli się immanentny konflikt wokół zamówień publicznych na usługi użyteczności publicznej. Odpowiedzialność za zapewnienie tych szczególnych usług spoczywa na państwie, przy czym z ponadnarodowego szczebla działalność ta jest monitorowana gwoli wyrównania warunków konkurencji. Od wielu już lat stanowi to realne wyzwanie dla wspólnotowej polityki stopniowej i kontrolowanej liberalizacji rynku. Drażliwy temat można zamknać w kwestii, komu zlecić usługę i na jakiej zasadzie. Cichym aktorem sporu, oprócz państwa i organów unijnych, są przedsiębiorstwa „o znacznej sile rynkowej”.

W roli wykonawców występują z reguły podmioty publiczne (lub ich skomercjalizowani bądź sprywatyzowani sukcesorzy), które wykonywały usługi użyteczności publicznej w krajach Unii jeszcze przed neoliberalną transformacją porządku gospodarczego z ostatnich dekad XX wieku. W języku branży mówi się o nich „zasiedziali operatorzy”. Tradycyjnie usługi użyteczności publicznej, czyli usługi pocztowe i telekomunikacyjne, usługi związane $\mathrm{z}$ infrastruktura transportową oraz $\mathrm{z}$ zaopatrzeniem w energię i wodę, należały do sektora publicznego, to znaczy państwo było bezpośrednio odpowiedzialne za zapewnienie ich świadczenia, które zlecało do wykonania przedsiębiorstwom państwowym na zasadzie podległości. Tym samym usługodawcy byli wyłączeni z konkurencji. Począwszy od lat osiemdziesiątych XX wieku, „odchudzanie" państwa w krajach europejskich doprowadziło do dzielenia odpowiedzialności w tym sensie, że państwo zapewnia tego typu usługi, ale niekoniecznie je „produkuje”, bo- 
wiem zadania zleca jednostkom spoza sektora publicznego na zasadzie umowy. Tendencję do tego swoistego outsourcingu wzmacnia nacisk Komisji Europejskiej na rzecz zapewnienia równego dostępu do zamówień wszystkim podmiotom, również tym prowadzącym działalność nastawioną na zysk. Tyle że niektóre państwa członkowskie wręcz podtrzymuja dominację operatorów zasiedziałych na terenie danego kraju, preferując ich usługi. Taki stan rzeczy w oczywisty sposób kłóci się z generalnym trendem unijnych regulacji, aby zapewnić wszystkim podmiotom równoprawny dostęp do zamówień publicznych. Z perspektywy jednolitego europejskiego rynku szczególny problem stanowi to, że utrwalone stosunki między państwami członkowskimi i krajowymi zasiedziałymi operatorami dyskryminują firmy działające w wymiarze transgranicznym.

Pokrótce, na przykładzie rynkowych usług użyteczności publicznej o charakterze powszechnym, omówiono problemy zrodzone przez ten układ. Za przyzwoleniem Unii w segmencie usług powszechnych narodowe organy publiczne mogą korzystać z narzędzi administracyjnych, rekompensat oraz praw własności (tabela 1.). Do naświetlenia sygnalizowanych na wstępie problemów najbardziej przydatne wydają się:

- $\quad$ spośród środków administracyjnych - zastrzeganie usług;

- $\quad$ w sferze rekompensat - te formy dochodów, które nabierają charakteru pomocy publicznej;

- $\quad$ spośród praw własności - upoważnienie do dysponowania infrastruktura.

Zgodnie $z$ unijnymi ramami prawnymi, niektóre $z$ usług powszechnych w pewnym zakresie mogą zostać zastrzeżone decyzją organów państwa członkowskiego dla wyznaczonych operatorów - jednego lub więcej. Dopuszcza to Dyrektywa w sprawie przejryystości stosunków finansowych między państwami cz̨tonkowskimi a przedsiebiorstwami publicznymi, a takize w sprawie przejryystości finansowej wewnatrz okesélonych przedsiebiorstw [Dyrektywa..., 2006, art. 2, litera f]. Zastrzeżenie w tym kontekście oznacza ograniczenie kręgu wykonawców na danym obszarze geograficznym do jednego operatora (prawa wyłączne) albo do kilku podmiotów (prawa specjalne). Rozpostarty przez państwo „parasol” usług zastrzeżonych sprzyja zatem przedmiotowej lub terytorialnej dominacji wybranych operatorów i jest oczywistym przykładem legalnego monopolu.

Wyznaczenie do świadczenia usług łączy się zwykle z przyznaniem rekompensat finansowych. Przyjęto, iż obowiązek świadczenia usług powszechnych jest nierentowny i stanowi ex definitione obciążenie finansowe, wobec czego zapewniono operatorowi z tytułu przyznania mu praw wyłącznych (ewentualnie specjalnych) dochody kompensujące ponoszone straty, co w znacznej mierze można przypisać skuteczności nacisków ze strony samych operatorów. Dyrektywa Parlamentu Europejskiego i Rady w sprawie wspólnych zasad rozwoju rynku wewnetrznego ustug pocztonych W spólnoty oraz poprany jakości ustug odnotowuje: konieczność prowadzenia driatalności w zakresie ustug powszechnych na podstawie zrównoważonych finansowo warunków [Dyrektywa..., 1997, preambuła, motyw 16]. Usankcjonowanie tego podejścia ma istotny wpływ na zdolność innych przedsiębiorstw do świadczenia tych samych usług lub prowadzenia analogicznej działalności na danym obszarze. Należy zauważyć, że kompensata kosztów netto (np. w formie zwolnień z opłat i podatków) przyznawana często hojnie i w sposób ekonomicznie nieuzasadniony, może 
stać się niejawną pomoca publiczna, która wzmacnia pozycję świadczących usługi przedsiębiorstw względem ewentualnej konkurencji.

Zachowanie przez operatorów zasiedziałych prawa do dysponowania infrastrukturą wydaje się nie mniej ważną, a nawet rozstrzygającą okolicznością, dzięki której zachowali oni pozycję krajowych potentatów. Choć dawny monopol został oficjalnie zlikwidowany, infrastrukturę używaną przed transformacją oddano im w zarząd. Z jednej strony unijna polityka konkurencji przewiduje powierzenie obowiązku świadczenia usługi powszechnej operatorom oferującym najbardziej efektywne cenowo sposoby zapewnienia usług i dostępu do nich, co bynajmniej nie wskazuje z góry na przedsiębiorstwa o znacznej sile rynkowej jako jedynych możliwych zwycięzców procedury wyboru. Z drugiej strony obowiązek świadczenia usługi powszechnej winien być spełniony w satysfakcjonujący jakościowo sposób, a powszechność usługi oznacza dostępność, co uprzywilejowuje wyraźnie podmioty dominujące. Tylko one bowiem posiadają odpowiednio rozwiniętą infrastrukturę bądź nieograniczony do niej dostęp. Prawo do dysponowania niezwykle rozbudowaną i kosztowną infrastrukturą jest w stanie „ustawiać” układ sił w całym sektorze i to znacznie skuteczniej, niż drogą formalnego ustanawiania obszarów zastrzeżonych. Właśnie te przedsiębiorstwa, które górują nad konkurencją dzięki infrastrukturze, są z reguły desygnowane do świadczenia usług powszechnych. Mimo iż taki „zasiedziały operator” poddany presji przez regulacje prawne związane z liberalizacją rynku jest „skłonny” udzielić do niej dostępu, warunki, jakie proponuje, czynią z takiej oferty ustępstwo pozorne, uniemożliwiające konkurentom skuteczne ubieganie się o zamówienie publiczne. Mamy zatem do czynienia z faktycznym monopolem na uzyskiwanie zleceń.

Ostatnie próby cementowania takiego monopolu stanowiły niedawne decyzje w naszym kraju w odniesieniu do Poczty Polskiej. Polskie prawo pocztowe, w następstwie nowelizacji w listopadzie 2012 roku, zostało dostosowane (przynajmniej formalnie) do postanowień wspomnianej Dyrektymy z 1997 roku, jednak jej wdrożenie postanowiono przesunąć do ostatniego, możliwego terminu ze względu na niedostateczne przygotowanie publicznego operatora pocztowego do prowadzenia działalności na zliberalizowanym rynku pocztowym.

TABELA 1.

Ochrona zasiedziałych operatorów: narzędzia administracyjne, prawne i ekonomiczne w gestii państwa

\begin{tabular}{|c|c|c|}
\hline Rodzaj narzędzia & Przykład narzędzia & Problem konkurencji \\
\hline środki administracyjne & zastrzeganie usług & legalny monopol \\
\hline rekompensaty finansowe & $\begin{array}{c}\text { zwolnienia z opłat i podat- } \\
\text { ków }\end{array}$ & pomoc publiczna \\
\hline prawa własności & $\begin{array}{c}\text { upoważnienie do dyspono- } \\
\text { wania infrastruktura }\end{array}$ & $\begin{array}{c}\text { faktyczny monopol na uzys- } \\
\text { kiwanie zleceń }\end{array}$ \\
\hline
\end{tabular}

Źródło: opracowanie własne.

Szczególne relacje między organami władzy publicznej a dominującymi operatorami zasiedziałymi są raczej reguła niż wyjątkiem. Ci ostatni, jak pokazała analiza, mogą czer- 
pać renty bądź z monopolu prawnego, bądź z faktycznego monopolu na uzyskiwanie zleceń, bądź z pomocy publicznej, która dyskryminuje innych dostawców. Na przykładzie usług powszechnych widać, jak państwo narodowe zdradza zawodność we wspieraniu ustroju opartego na konkurencji. Wprawdzie na ogół działa w ramach ustanowionych przez Unię, jednak przynależne mu prawa do wyboru preferowanych instrumentów sterowania odnośnymi usługami wyrastają lub funkcjonują na gruncie tradycyjnych, głęboko zakorzenionych struktur zorganizowanych na bazie monopoli krajowych.

Czy nadzór Unii nad państwami członkowskimi stwarza szanse na obalenie barier w dostępie do zleceń na usługi powszechne, które wynikają ze szczególnych stosunków z zasiedziałymi operatorami? Na to pytanie nie można odpowiedzieć twierdząco. Prawo Unii w tym względzie jest miękkie i pragmatyczne. Na przykład wspomniana Dyrektywa z 2002 roku pozostawia państwom dużą swobodę w wyborze operatora, która umożliwia pominięcie procedury przetargu na usługi powszechne [Dyrektywa ..., 2002, art. 8 pkt. 2]. W przypadku tych usług, które przecież muszą być świadczone także użytkownikom „nieekonomicznym”, wystarczą „starania w celu minimalizacji naruszeń rynku” oraz zasada, że żadne przedsiębiorstwo nie jest z góry wykluczone z procesu wyznaczania. W kolejnych sektorowych dyrektywach Parlamentu Europejskiego i Rady w sprawie usługi powszechnej, od drugiej połowy lat dziewięćdziesiątych począwszy, jednym z punktów ciężkości jest stymulowanie procesu stopniowego „rozmontowywania” pozostałości tradycyjnych monopoli funkcjonujących jeszcze w sferze usług użyteczności publicznej. Niemniej „siłowe” wymuszanie przez Komisję przyspieszonego procesu europejskiej integracji zorientowanej na stworzenie w pełni zharmonizowanego wspólnego rynku usług użyteczności publicznej już niejednokrotnie de facto kończyło się zablokowaniem (lub co najmniej spowolnieniem) tych zmian przez władze publiczne niektórych krajów członkowskich. W takich sytuacjach napięcie między Komisją i państwami narodowymi rodzi utożsamianie przez te ostatnie owych prób z koniecznością zrzeczenia się przez nie części posiadanych prerogatyw i przeniesieniem ich z poziomu krajowego na wspólnotowy.

Unia Europejska, jak dotąd, wydaje się zbyt słaba, aby przełamać układ istniejący między państwem narodowym a rodzimymi firmami w sektorze powszechnych usług użyteczności publicznej, korzystającymi z monopolu prawnego i z innych form uprzywilejowania. Liberalizacyjna misja Unii znalazła wyraz w ważnej dla tego casusu Dyrektywie z 2002 roku, którą we fragmencie warto zacytować: rozwój większej konkurencyjności

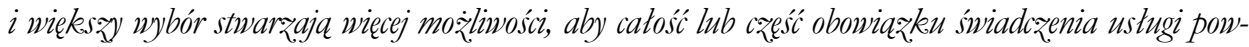
szechnej by ta wypetniana pržez, przedsiebiorstwa inne niž, te o znacznej sile rynkowej [Dyrektywa..., 2002, motyw 14 preambuły]. Zapis ten oddaje przyszłościową wizję wolnej konkurencji w duchu Euckena. Jednakże, aby idea ta spełniła się, choćby w segmencie usług powszechnych, musi dojść do wykorzenienia struktur zorganizowanych na bazie monopoli krajowych. Dokonany przegląd pokazuje, że względy społeczne i polityczne na to nie pozwalaja. W szczególności Unia nie wydaje się gotowa na konfrontacje z wielkimi firmami z sektorów sieciowych ani z wspierającymi „swoje” firmy państwami. Tak długo, jak będzie na to za słaba, głoszona zasada konkurencji w sensie euckenowskim będzie w dalszym ciagu należała do przyszłości. 


\section{Podsumowanie}

W artykule starano się zwrócić uwagę na pewne aspekty liberalizmu, odnosząc się do doświadczenia Unii Europejskiej. Misja budowy jednolitego rynku zdaje się podażać za euckenowską ideą ustroju opartego na konkurencji. Niezbywalnym warunkiem tego ustroju jest podtrzymywanie wartości, od których zależy spójność społeczeństwa. Ze względu na ordoliberalne dziedzictwo intelektualne, jak i powojenną tradycję polityczną ujednolicanie reguł we wspólnej europejskiej przestrzeni gospodarczej gwoli konkurencji sprzężono z aspektami społecznymi (społeczna gospodarka rynkowa). Zgodnie $z$ ta wizją, liberalizacja jest rozumiana jako tworzenie konstytucyjnych ram raczej dla wolnej konkurencji niż jako samoograniczenie państwa.

Ponadto przyjęcie euckenowskiej perspektywy pokazuje, że na przeszkodzie liberalizacji stoi nie tylko skłonność władzy publicznej do ingerowania w stosunki gospodarcze, lecz także określone zachowania uczestników rynku. W kontekście tego artykułu chodzi o przedsiębiorstwa „o znacznej sile rynkowej”, które zapewniły sobie specjalne stosunki z władzą i stanowią istotna grupę interesu na rzecz zachowania tradycyjnych, głęboko zakorzenionych struktur. Ponad pół wieku po opublikowaniu dzieła Euckena i blisko ćwierć wieku po powołaniu Unii Europejskiej nie ma wątpliwości, że zarówno państwa narodowe, jak i europejskie organa ponadnarodowe okazały się zbyt słabe, aby zmniejszyć znaczenie tej bariery wolnej konkurencji. Rozmiary, które osiągnęły w tym czasie niektóre europejskie ugrupowania biznesowe i grupy bankowe, przekraczające często produkt macierzystych krajów, nie pozostawiaja złudzeń co do tego, iż państwo $\mathrm{w}$ najbardziej rozwiniętych gospodarkach kapitalistycznych w dalszym ciagu jest podatne na lobbing „grup dominujących”. Opisany przykład regulacji powszechnych usług użyteczności publicznej nie wskazuje na to, aby nadzór na ponadnarodowym szczeblu Unii Europejskiej mógł wykorzenić struktury zorganizowane na bazie monopoli krajowych i protektoratu państwowego. Euckenowski dylemat czeka na rozwiązanie.

\section{Literatura}

Dyrektywa 2002/22/WE Parlamentu Europejskiego $i$ Rady w sprawie ustugi powszechnej $i$ inviazamych z sieciami i ustugami taczności elektronicznej praw usyttoonmikón z dnia 7 marca 2002 roku, Dz. U. L 108, 24.04.2002.

Dyrektywa 97/67/WE Parlamentu Europejskiego i Rady w sprawie wspólnych zasad rozwoju bynku wewnetržnego ustug pocztonych W spólnoty oraz poprany jakości ustug z dnia 15 grudnia 1997 roku, Dz. U. L 15, 21.01.1998.

Dyrektywa Komisji 2006/111/WE w sprawie przejraystości stosunków finansonych miedsy państwami ç̧onkowskimi a przedsiebiorstwami publicznymi, a takize w sprawie przejraystości finansowej wewnatry okesélonych przedsiebiorstw z dnia 16 listopada 2006 roku, Dz. U. L318, 17.11.2006.

Eucken W. 2005 Podstany polityki gospodarczej (Grundsaetze der Wirtschaftspolitik), Wydawnictwo Poznańskie, Poznań. 
Federowicz M. 2004 Różnorodność kapitalizmu. Instytucjonaližm i doświadczenie żmiany ustrojowej po komunizmie, Wydawnictwo Instytutu Filozofii i Socjologii PAN, Warszawa.

Komunikat Komisji do Parlamentu Europejskiego, Rady, Komitetu Ekonomiczno-Spolecznego oraz. Komitetu Regionów. Biała Ksiega na temat ustug u̇ìteczności publicznej, Komisja Wspólnot Europejskich, Bruksela, COM (2004) 374, wersja ostateczna, dokument elektroniczny, tryb dostępu: [http:eur-lex.europa.eu/LexUriServ/site/pl/com/2004/ com2004_0374pl01.pdf, data wejścia: 12.05.2004].

Manifest Międzynarodowej Asocjacii Liberatów, 1981, Rzym.

Sadowski Z. 1996 Jaki kapitalizm? Modelowe trendy i kierunki polityki, Rada Strategii Społeczno-Gospodarczej, Warszawa.

Społeczna gospodarka rynkowa. Idee i możliwości praktycznego wykorzystania w Polsce 2003, E. Mączyńska E., P. Pysz (red.), Polskie Towarzystwo Ekonomiczne, Warszawa.

Teoria wyboru publicznego. Glówne nurty $i$ zastosowania 2012, J. Wilkin (red.), Wydawnictwo Naukowe Scholar, Warszawa.

Traktat o funkecjonowaniu Unii Europejskiej, 2010, wersja skonsolidowana, Dziennik Urzędowy Unii Europejskiej, C/83/47, 30.03.2010.

Walicki A. (w rozmowie z K. Pilawskim) 2013 Bez sprawiedliwości nie ma wolności, „Przegląd”, 9-15.12.

Wojtyna A. 1994 Neoliberalne poglady we wspótczesnej polskiej myśli ekonomicznej i ich wpływ na ksztalt modelu transformacji, Zeszyty Naukowe Carl Menger Research Center, Warszawa.

Ząbkowicz A., Ząbkowicz J. 2013 Kontrolowana liberalizacja versus niechęć do konkurencii na prayketadzie rynku ustug u̇̇yteczności publicznej w Unii Europejskiej, „Ekonomia”, Uniwersytet Ekonomiczny we Wrocławiu, nr 4(25).

Ząbkowicz A. 2013 Problem władzy w ordoliberalnej koncepcji tadu i spoleczna gospodarka rynkowa, [w:] Idee liberalne w ekonomii 20 lat po śmierci Friedricha von Hayeka, R. Ciborowski, A. Kargol-Wasiluk, M. Zalesko (red.), Wydawnictwo Uniwersytetu w Białymstoku, Białystok. 